\title{
Oncologische nazorg bij de
}

\section{huisarts}

Onlangs was ik bij een nascholing van huisartsen en specialisten die begon met de stelling dat oncologische nazorg een taak van de huisarts is. De meningen waren verdeeld. Een relevant probleem, want krijgt de huisarts er weer een taak bij? Omdat de levensverwachting van kankerpatiënten door betere behandeling (chirurgie, radiotherapie, chemo-immunotherapie en complicatiepreventie) sterk toegenomen is, gaat het om grote aantallen patiënten. De gemiddelde vijfjaarsoverleving is nu bijna 60\% tegen 30\% zo'n 40 jaar geleden. Een normpraktijk heeft per jaar 15 tot 25 nieuwe patiënten met de diagnose kanker. Deze vragen veel zorg in de periode van de diagnose, initiële behandeling en in de eerste jaren daarna. Overheid en zorgverzekeraars willen de hoogcomplexe zorg in de tweede lijn en de controles in de eerste lijn. Zo staat het in hoofdlijnenakkoord medisch-specialistische zorg, dat zonder de eerste lijn tot stand is gekomen. Oncologen zijn verdeeld over de vraag wie wat moet doen. Veelal gaat het om sterk geprotocolleerde zorg, die vaak door verpleegkundigen wordt gedaan. Menig specialist vindt het behouden van dit type zorg tussen alle complexe vraagstukken door juist wel prettig!

Huisartsen zien belemmeringen op het gebied van deskundigheid, ervaring, tijd, middelen, samenwerking en patiëntpreferenties. En zij vinden dat deze nazorg duidelijk meerwaarde moet hebben.

Hoe denken kankeroverlevers er zelf over? Brandenbarg laat in zijn artikel zien dat voor hen de psychosociale begeleiding en continuiteit van zorg van groot belang zijn, naast medische aspecten. Laten wij huisartsen(praktijk) nu net van onszelf vinden dat we daar best goed in zijn! De medische aspecten kunnen we leren, zoals we gedaan hebben bij de chronische aandoeningen. Ook bij oncologische nazorg kunnen we ondersteund worden door een praktijkondersteuner of verpleegkundige. En we kunnen daarbij het organisatiemodel van de chronische zorg gebruiken (onder meer voor de randvoorwaarden).

$\mathrm{Na}$ een stevige discussie over nazorg bij kankerpatiënten op de nascholing, was een ruime meerderheid voorstander om de rol van de huisarts hierbij verder te bekijken. Natuurlijk met goede financiering, deskundigheidsbevordering, samenwerking, protocollen, et cetera. Tijd om hier eens werk van te maken. -

Ivo Smeele
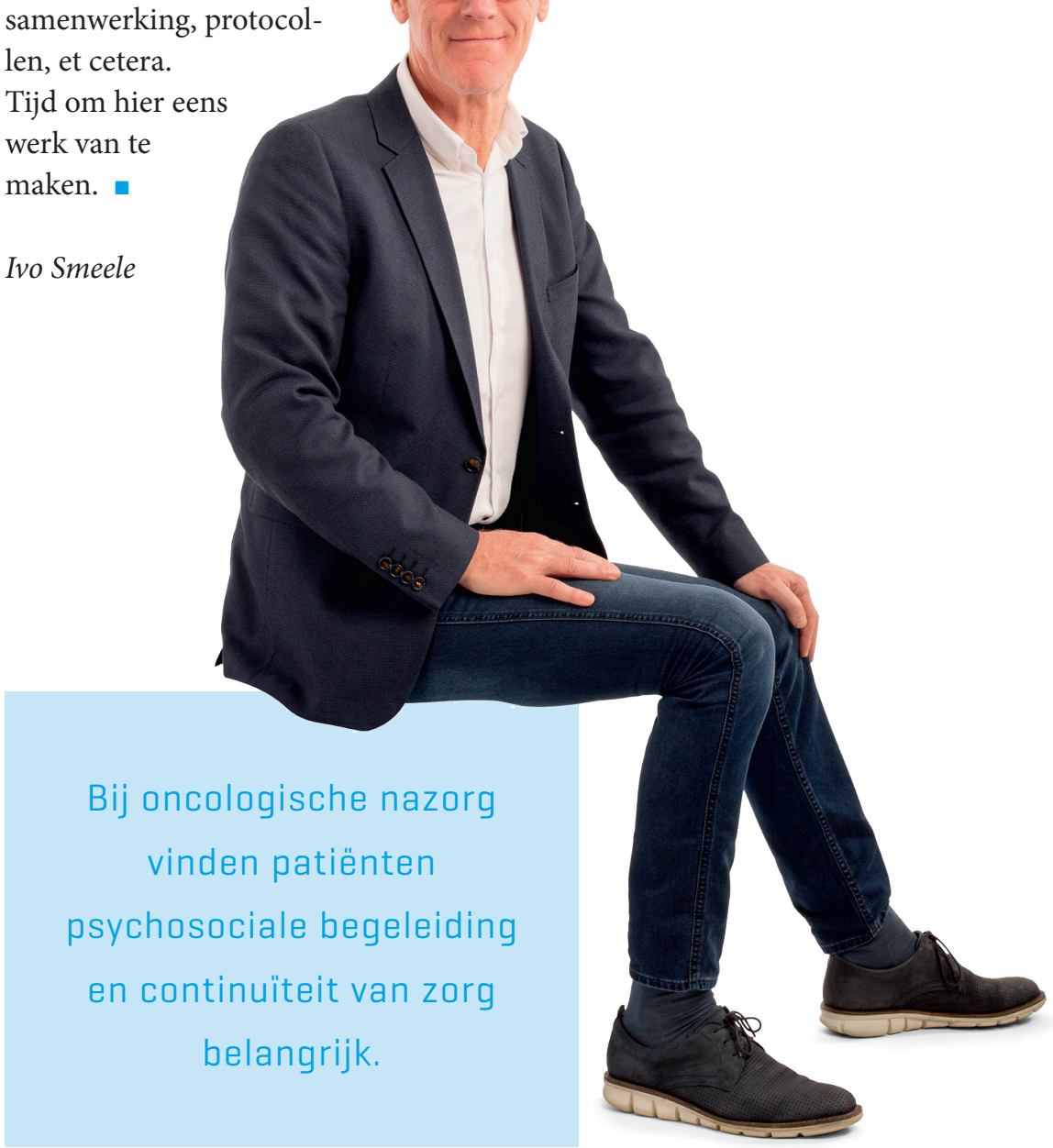